\title{
A Study on Financial Statement Analysis in Tamil Nadu Newsprint and Papers Limited, Kagithapuram, Karur
}

\section{Sassikala A*}

M. Kumarasamy College of Engineering, Karur, Tamil Nadu, India

\begin{abstract}
This project report entitled as "A Study on Financial Statement Analysis. In Tamil Nadu Newsprint and Papers Limited, Kagithapuram", is done as a part of MBA curriculum. The objective of the study is to analysis the financial statement of Tamil Nadu Newsprint and Papers Limited, Kagithapuram. The study is carried for a period of five years from 2012-2013 to 2016-2017. Data were collected from the secondary sources. To identify the financial statements of the company and al so understand the liquidity position. The tools used for analysis, Comparative Balance Sheet, Common Size Balance Sheet, Ratio Analysis.
\end{abstract}

Keywords: Financial statement analysis; TNPL; Paper mill; Financial management

\section{Introduction}

Financial statement analysis is the process of reviewing and evaluating a company's financial statements (such as the balance sheet or profit and loss statement), thereby gaining an understanding of the financial health of the company and enabling more effective decision making.

\section{About the Company}

The Tamil Nadu Newsprint and Papers Limited (TNPL) was established by the Government of Tamil Nadu to produce newsprint and writing paper using bagasse, a sugarcane residue. The Company commenced production in the year 1984 with an initial capacity of 90,000 tonnes per annum. Now TNPL has two Units. One unit in Kagithapuram and another in Mondipatti [1].

\section{Industry Analysis}

Paper is produced in India primarily in many states. The first paper mill was started in Serampore (West Bengal) in 1812 and other Paper mill are Royal Paper Mills (1867), Upper India Couper Mills (1879), Titaghar Paper Mills (1882), and Deccan Paper mills (1887) started with a total annual installed capacity of 5,000 tonnes [2]

\section{Statement of the Problem}

The analysis of the financial statements i.e., balance sheet it is very difficult to analyze the complete picture of financial statements. Therefore, there is a need of applying the modern tools of management accounting to access the exact financial statement and position of the business enterprise [3]. According ratios are relationships expressed in mathematical terms between the figures that are connected with each other in some manner.

\section{Objective}

- The Financial analysis of selected company TNPL has been undertaken with the following objectives.

- To identify the financial statements of the company.

- To analyze the statements of the company with the help of tools like comparative balance sheet, common-size balance, ratio analysis.
- Assessment of Past Performance and Assessment of current position.

- Prediction of bankruptcy and failure.

- To assess the operational efficiency of the management of a company.

- To assess in depth the liquidity, efficiency and profitability of selected companies.

- To make suggestions for improving financial position of selected companies.

\section{Scope of the Study}

The study has conducted mainly to evaluate the financial strength of The Tamil Nadu Newsprint and Papers Limited, Kagithapuram for a period of 5 years from 2012-13 to 2016-17 as revealed from the financial data of the company annual report, manuals and accounting records [4].

- It helps in the analysis of financial operation.

- It helps in proper allocation of funds.

- Helps in the use and changes in working capital.

- It helps in knowing the overall credit worthiness of the firm.

- The company can make managerial decisions, planning, and control regarding the financial management.

\section{Data Analysis and Interpretation and Findings}

\section{Ratio analysis}

Profitability ratio: Interpretation: The Figure 1 indicates the gross profit ratio of the company during the study period of 2013-2017. The

*Corresponding author: Sassikala A, M. Kumarasamy College of Engineering, Karur, Tamil Nadu, India, Tel: 04324272155; E-mail: asassikala@gmail.com

Received April 05, 2018; Accepted May 10, 2018; Published May 20, 2018

Citation: Sassikala A (2018) A Study on Financial Statement Analysis in Tamil Nadu Newsprint and Papers Limited, Kagithapuram, Karur. J Bus Fin Aff 7: 337 doi: 10.4172/2167-0234.1000337

Copyright: (c) 2018 Sassikala A. This is an open-access article distributed under the terms of the Creative Commons Attribution License, which permits unrestricted use, distribution, and reproduction in any medium, provided the original author and source are credited. 
Citation: Sassikala A (2018) A Study on Financial Statement Analysis in Tamil Nadu Newsprint and Papers Limited, Kagithapuram, Karur. J Bus Fin Aff 7: 337. doi: 10.4172/2167-0234.1000337

Page 2 of 5

highest percentage was 13.12 in the year 2016 and the lowest percentage was 6.78 in the year 2013.

Net profit ratio: Interpretation: The Figure 2 indicates the net profit ratio of the company during the study period of 2013-2017. The highest percentage was 10.50 in the year 2016 and the lowest percentage was 3.30 in the year 2013 .

Operating profit ratio: Interpretation: The Figure 3 indicates the operating profit ratio of the company during the study period of 20132017. The highest percentage was 25.97 in the year 2017 and the lowest percentage was 22.68 in the year 2013 .

Expenses ratio: Interpretation: The Figure 4 indicates the expenses ratio of the company during the study period of 2013-2017. The highest percentage was 3.74 in the year 2015 and the lowest percentage was 2.46 in the year 2014 .

Liquidity ratio: Interpretation: The Figure 5 indicates the current ratio of the company during the study period of 2013-2017. The highest ratio was 0.80 in the year 2017 and the lowest ratio was 0.59 in the year 2013.

Liquid ratio or acid ratio: Interpretation: The Figure 6 indicates the liquid ratio of the company during the study period of 2013-2017. The highest ratio was 0.72 in the year 2017 and the lowest ratio was 0.28 in the year 2013.

Solvency ratio: Interpretation: The Figure 7 indicates the debt equity ratio of the company during the study period of 2013-2017. The
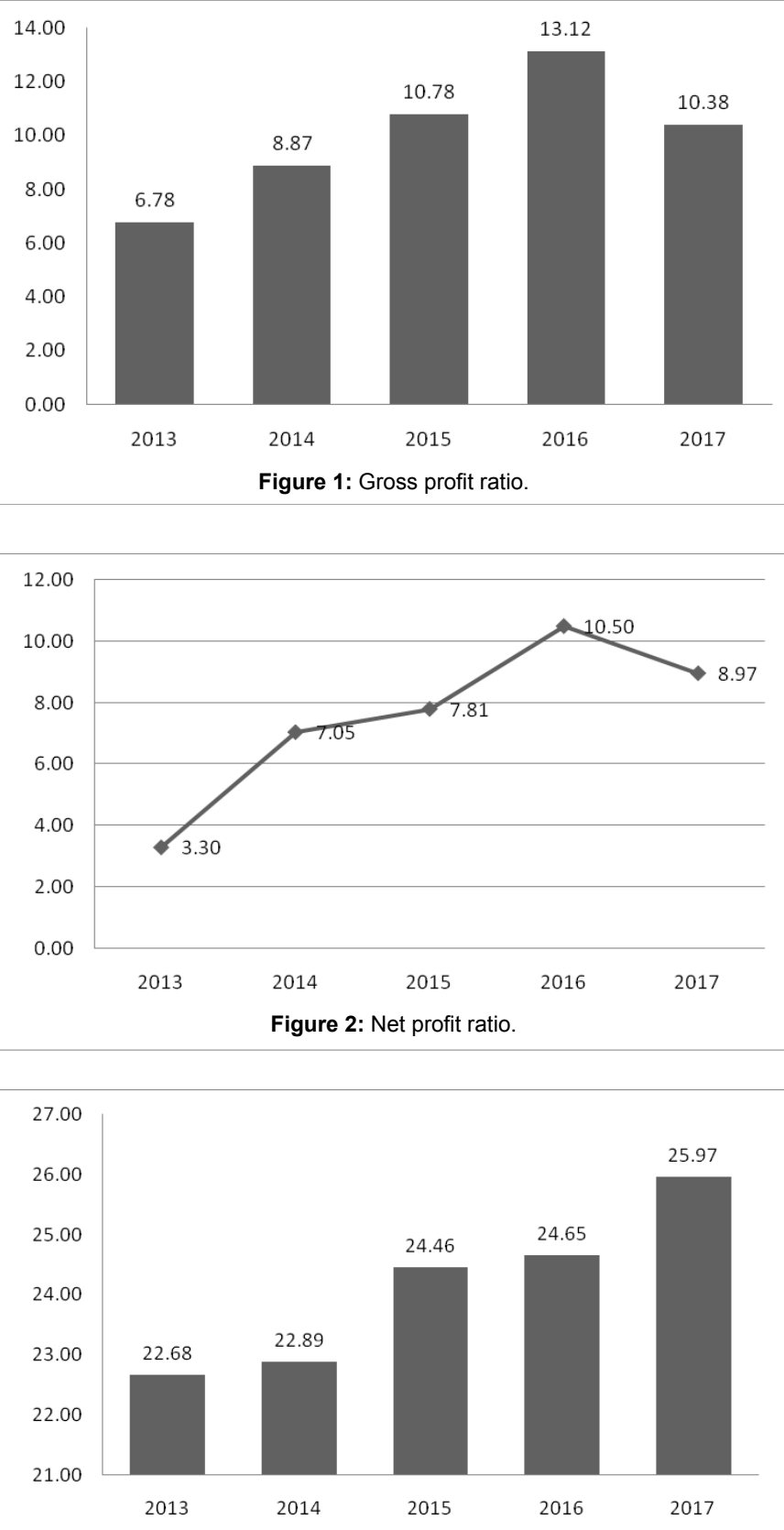

Figure 3: Operating profit ratio. 

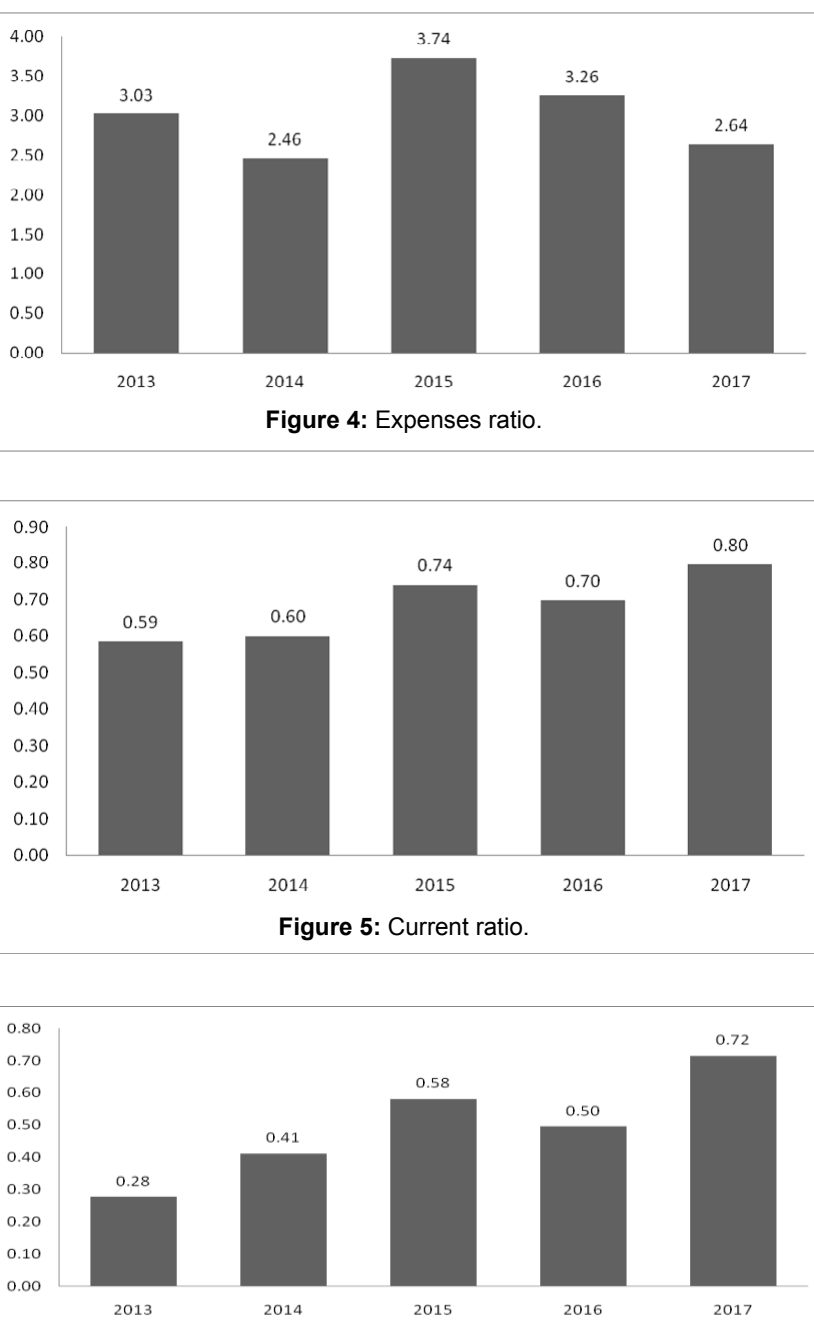

Figure 6: Liquid ratio or acid ratio.

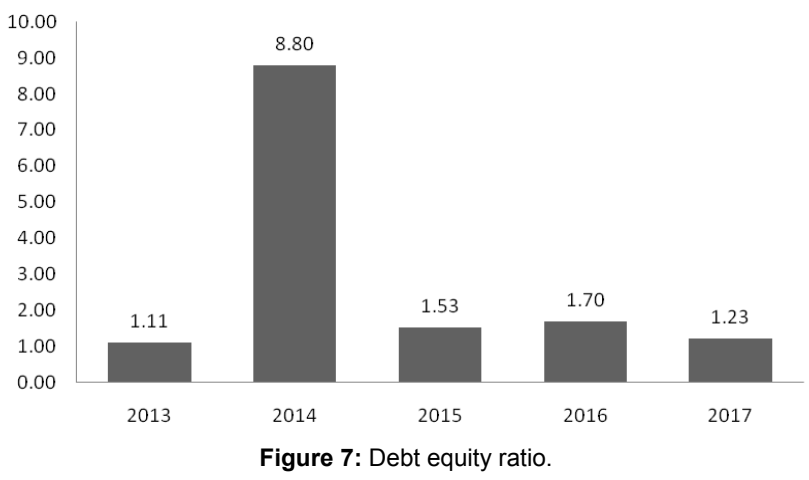

highest ratio was 8.80 in the year 2014 and the lowest ratio was 1.11 in the year 2013 .

Proprietary ratio: Interpretation: The Figure 8 indicates the proprietary ratio of the company during the study period of 2013-2017. The highest ratio was 0.33 in the year 2017 and the lowest ratio was 0.26 in the year 2015 and 2016.

Turnover ratio: Interpretation: The Figure 9 indicates the stock turnover ratio of the company during the study period of 2013-2017.
The highest ratio was 8.21 in the year 2014 and the lowest ratio was 5.05 in the year 2015.

Fixed asset ratio: Interpretation: The Figure 10 indicates the stock turnover ratio of the company during the study period of 2013-2017. The highest ratio was 1.39 in the year 2013 and the lowest ratio was 0.64 in the year 2016.

Working capital turnover ratio: Interpretation: The Figure 11 

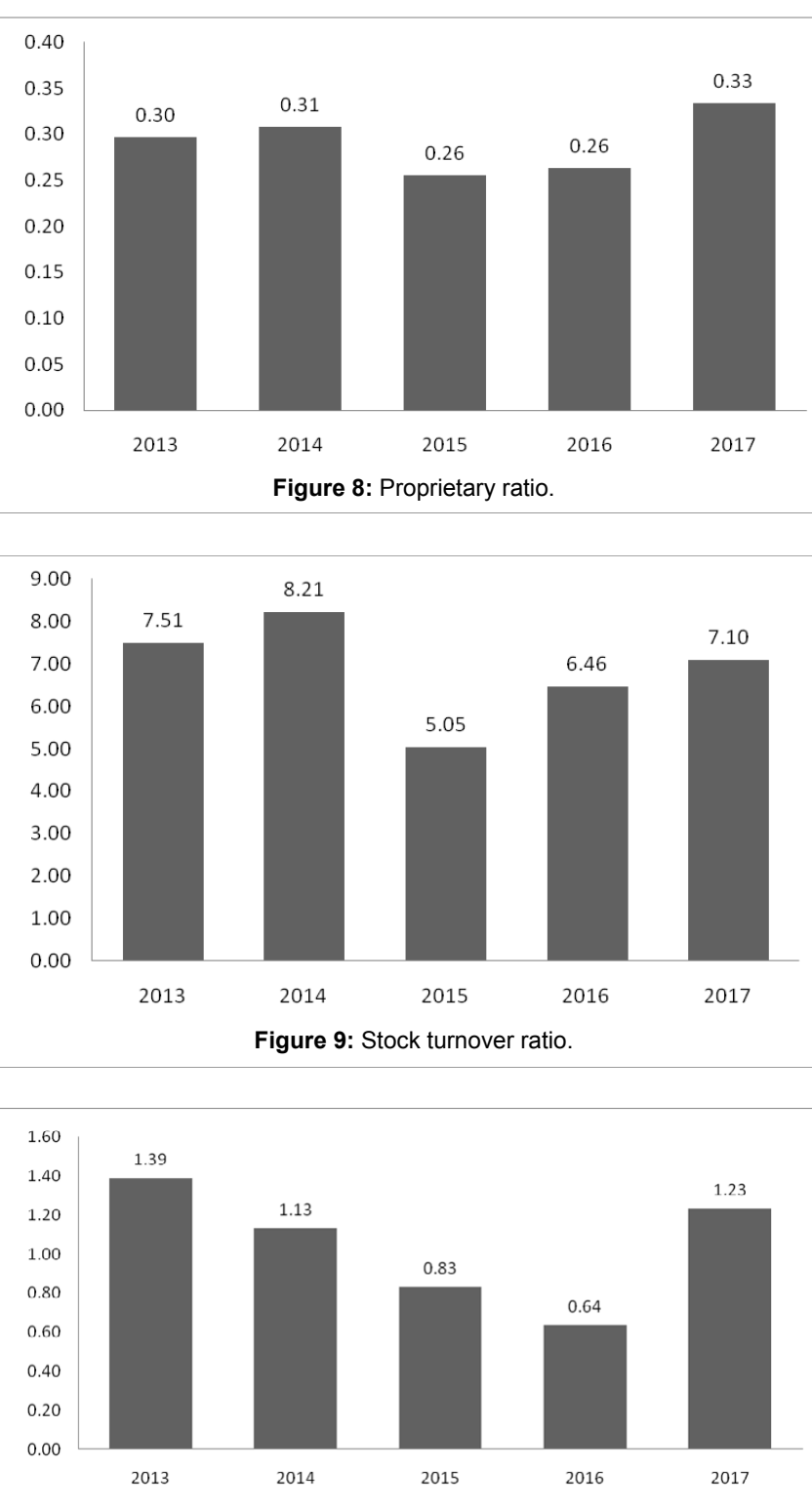

Figure 10: Fixed asset ratio.

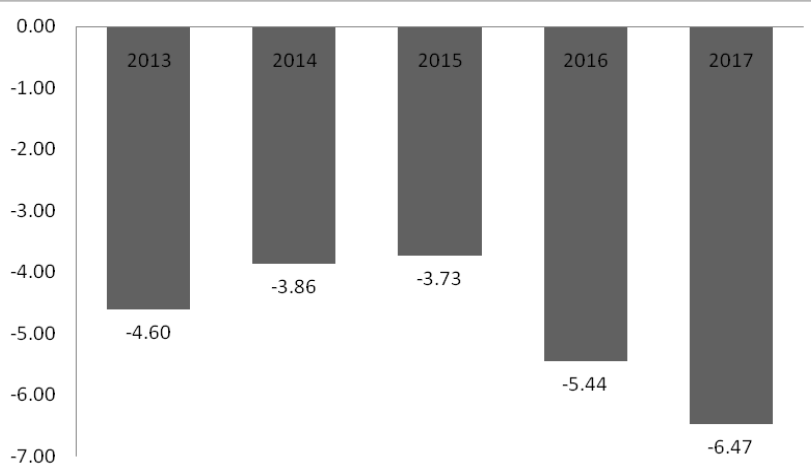

Figure 11: Working capital turnover ratio.

indicates the stock turnover ratio of the company during the study period of 2013-2017. The highest ratio was -6.47 in the year 2017 and the lowest ratio was -3.73 in the year 2015 .

\section{Suggestions}

- The company was able to earn profit during the study period. Hence the same level of operation can be continued. 
- The management of the company should to control over its expenses as it is more than the normal.

- The company was able to maintain the stock turnover ratio during the study period. The management should continue the same.

- The company was able to maintain inadequate working capital during the study period. So, the increase on working capital to be continued the level of operation.

- The company was increase on current assets and decrease on current liabilities.

- The management of the company has concentrate more on the fixed assets to increase it.

- The management of the company has to concentrate on shareholder's fund and the reserves.

- Thrust has to be given for liquidation of debtors who are more than 3 years.

- A coordination team may be formed for collection from debtors of various units/product.

- Periodic review may be enhanced to reduce non-moving and slow-moving stock of effective control of inventory.

\section{Conclusion}

From this study of Tamil Nadu Newsprint and Papers Limited entitled "FINANCIAL STATEMENT ANALYSIS". This is fully based on the past five year's reports. The study also provided knowledge about the comparative balance sheet, common size balance sheet and ratio analysis, which capture the predicative variability of company financial statement.

The analysis has shown fluctuations and have both good and bad sides during five years. The performance of the company seems to be in increase every year because of the increase in sales but the efficient management of adapting to changes is needed to run towards success. The company is having good reserves and reputation, which will lead to excellent progress in the fore coming years.

\section{Acknowledgements}

This work was supported by Tamil Nadu Newsprint and Papers Limited, Kagithapuram, Karur, Tamil Nadu and is purely done for study purpose.

\section{References}

1. Khan MY, Jain PK (2008) Financial management.

2. Pandey IM (2008) Financial management. (10th edn.), Vikas Publishing House Pvt. Ltd., New Delhi.

3. Prasanna Chandra (2008) Financial Management Theory and Practice. Tata McGraw Hill publishing company Ltd, New Delhi.

4. Maheswari SN (2014) Elements of Financial Management. Sultan Chand \& Sons, Educational Publishers, New Delhi. 